\title{
Red-jambo peel extract shows antiproliferative activity against HepG2 human hepatoma cells
}

\author{
Milena Morandi Vuolo ${ }^{\mathrm{a}}$, Ângela Giovana Batista ${ }^{\mathrm{a}, \mathrm{b}}$, Aline Camarão Telles Biasoto ${ }^{\mathrm{c}}$, \\ Luiz Claudio Correa ${ }^{\mathrm{c}}$, Mário Roberto Maróstica Júnior ${ }^{\mathrm{a}, *}$, Rui Hai Liu ${ }^{\mathrm{d}}$ \\ ${ }^{a}$ School of Food Engineering, University of Campinas (UNICAMP), P.O. Box 6121, 13083-862 Campinas, SP, Brazil \\ ${ }^{\mathrm{b}}$ Department of Food and Nutrition, Federal University of Santa Maria (UFSM), Palmeira das Missões, RS 98300-000, Brazil \\ ${ }^{\mathrm{c}}$ Brazilian Agricultural Research Corporation, Embrapa Tropical Semi-arid, Petrolina, PE 56302-970, Brazil \\ d Department of Food Science, Cornell University, Ithaca, NY ZIP 14850-2824, USA
}

\section{A R T I C L E I N F O}

\section{Keywords:}

Syzygium malaccence

Myrtaceae

Malay apple

Cellular antioxidant activity

Antiproliferative activity

\begin{abstract}
A B S T R A C T
The peel of the red-jambo concentrates the majority of the bioactive compounds and antioxidant capacity of the fruit. Minor phenolic compounds in this part of the fruit are still unknown, as well as the effect of its extracts in in vitro and in vivo studies. In an ethanolic extract of red-jambo, a wider range of phenolic compounds was investigated and the antioxidant cellular antioxidant activity and inhibition of HepG2 cell proliferation were evaluated for the first time. Using HPLC-FLD/DAD for phenolic compounds determination, gallic acid, chlorogenic acid and (-)-epigallocatechin gallate were found for the first time in the peel of the red-jambo fruit. The anthocyanins found (cyanidin 3,5-diglucoside, cyanidin 3-glucoside and peonidin 3-glucoside) were the flavonoid class strongly correlated with the antioxidant capacity methods used in this study (cellular antioxidant activity and oxygen radical absorbance capacity). The ethanolic extract of the peel showed significant effect on reducing the tumoral cell growth and proliferation. Antiproliferative activity of phytochemicals showed no significant correlative relations with total phenolic compounds, flavonoids and anthocyanins, demonstrating which the antiproliferative effect of the extract could be due to the synergic action among the compounds in redjambo peel.
\end{abstract}

\section{Introduction}

(Poly)phenols present in plants are powerful free radical scavengers recognized by their antioxidant and antitumoral effects (Leite et al. 2011; Leite-Legatti et al. 2012; Lewandowska, Kalinowska, Lewandowski, Stepkowski, \& Brzóska 2016; Roleira et al. 2015). The free radicals are highly reactive molecules with unpaired electrons that rapidly bind to nearby molecules (Prescott \& Bottle 2017), such as the reactive oxygen species (ROS) and reactive nitrogen species (RNS). These oxidants are produced as a result of normal metabolism in the intracellular mitochondria and peroxisomes, and other cytosolic enzyme systems, although external agents or injuries could trigger the overproduction of the reactive species (Prescott \& Bottle 2017). An excess of ROS and RNS can damage the cell membrane, proteins and DNA; impairing cellular function and even lead to cell death (Wiseman \& Halliwell 1996).

The so called oxidative stress, the imbalance between the biological or dietary antioxidant defenses and the overproduction of free radicals, play an important role on the development of many different physiological disorders, especially cancer (Ye, Zhang, Townsend, \& Tew 2015). In this context, oxidative stress could cause mutations, delay apoptosis by suppressing caspases and impair the cell cycle promoting tumoral cell growth and propagation (Ye et al. 2015).

Dietary (poly)phenols, have the capacity to prevent and minimize oxidative stress due to its antioxidant activity (Leite-Legatti et al. 2012; Lewandowska et al. 2016). Phenolic compounds are able to modulate cell metabolism and survival by activating or suppressing transcription factors and control the expression of genes involved on tumoral cell growth (Pistollato, Giampieri, \& Battino 2015). Extracts of berry fruits have shown great quantities of phenolic compounds, mainly anthocyanins, which are pigments responsible for their blue, red or purple colors (Bueno et al. 2012; Leite-Legatti et al. 2012; Wu et al. 2017).

As well as the berries, Syzygium malaccence red fruit, also known as red-jambo in Brazil or Malay apple in Malaysia, has a waxy and crimson peel containing interesting anthocyanins and other phytochemicals (Batista et al. 2017; Nunes, de Aquino, Rockenbach, \& Stamford 2016).

\footnotetext{
* Corresponding author at: Departamento de Alimentos e Nutrição. Rua Monteiro Lobato, 80. Cidade Universitária. Campinas-SP, 13083-862, Brasil.

E-mail address: mmarosti@unicamp.br (M.R.M. Júnior).
} 
As the peel concentrates the majority of the bioactive compounds and antioxidant capacity of the red-jambo fruit (Augusta, Resende, Borges, Maia, \& Couto 2010; Batista et al. 2017), further investigations in this part of the fruit are incited. Tree anthocyanins have been identified in polar extracts made of red-jambo fruit peel so far, such as cyanidin 3,5diglucoside, cyanidin 3-glucoside and peonidin 3-glucoside (Batista et al. 2017; Nunes et al. 2016). Studies have shown the potential effect of cyanidin 3-glucoside, the major anthocyanin in the red-jambo peel, against oxidative stress damage and positive effects on inflammatory diseases and tumoral cell proliferation (Kumar, Gautam, \& Sharma 2013; Matsukawa, Inaguma, Han, Villareal, \& Isoda 2015). However, little is known about the bioavailability of this compounds when administrated as part of a complex matrix as fruits. Even that some studies have reported major compounds in red-jambo peel phenolic composition, minor compounds in this part of the fruit are still unknown, as well as the effect of its extracts in in vitro and in vivo studies. Furthermore, the use of only traditional antioxidants methods to evaluate antioxidant activity is a concern in food science.

Considering the lack of reports about the effect of red-jambo peel on tumoral cell proliferation and cytotoxicity, the aim of this study was to investigate a wider range of phenolic compounds in an ethanolic extract of red-jambo peel and assess its antioxidant activity by cellular antioxidant methods. The cell model for measurement of antioxidant activity provides a better understanding of phytochemicals dynamic than traditional methods; as well as predict metabolism, uptake and distribution of the bioactive compounds some in the biological system (Wolfe \& Rui 2007). Furthermore, the present study looked into the cytotoxicity and antiproliferative effect of the ethanolic extract of redjambo peel on HepG2 (human hepatoma) cell line.

\section{Material and methods}

\subsection{Chemical compounds}

Ascorbic acid, 29, 79- dichlorofluorescin diaacetate (DCFH-DA), fluorescein disodium salt, sodium borohydride ( $\mathrm{NaBH} 4$, reagent grade), chloranil (analytical grade), vanillin (analytical grade), quercetin dehydrated, catechin hydrated, Folin-Ciocalteu reagent, 6-hydroxy-2, 5, 7, 8- tetramethylchroman-2-carboxylic acid (Trolox) were purchased from Sigma-Aldrich, Inc. (St. Louis, MO). HepG2 liver cancer cells were obtained from the American Type Culture Collection (ATCC) (Rockville, MD). Williams' Medium E (WME) and Hanks' Balanced Salt Solution (HBSS) were purchased from Gibco Life Technologies (Grand Island, NY). Fetal bovine serum (FBS) was obtained from Atlanta Biologicals (Lawrenceville, GA).

\subsection{Fruits}

The red-jambo ( $S$. malaccence) fruits were purchased at the local market CEASA in Campinas, SP, Brazil in February 2013. The fruits were peeled manually using a peeler and the peels were then freezedried in a freeze-dryer (LP1010, Liobras, São Carlos, SP, Brazil) at temperatures ranging from -40 to $25^{\circ} \mathrm{C}, 300 \mu \mathrm{m} \mathrm{Hg}$ for $95 \mathrm{~h}$, crushed, homogenized and frozen at $-18 \pm 5{ }^{\circ} \mathrm{C}$.

\subsubsection{Extraction}

An ethanolic extract of $25 \mathrm{~g}$ red-jambo peel was prepared by 3 times maceration with $100 \mathrm{~mL}$ of $99.5 \%$ ethanol using horizontal rotation, at room temperature $\left(20^{\circ} \mathrm{C} \pm 2\right)$. The ethanol was then evaporated, suspended in ultrapure water with a final volume of $50 \mathrm{~mL}$ for the cell assay and freeze-dried (44.82\% yield) for the chromatography and colorimetric assays (Batista et al. 2016).

\subsubsection{Polyphenols determination}

The total phenolic content was determined by the Folin-Ciocalteu method (Swain \& Hillis 1959), when water, Folin-Ciocalteau reagent and sodium carbonate were added to the extract. Two hours later, the absorbance of samples and standard curve was read at $725 \mathrm{~nm}$. The results were expressed as mg of gallic acid equivalents (GAE) $\mathrm{g}^{-1}$ of sample.

In order to determine total yellow flavonoids (Zhishen, Mengcheng, \& Jianming 1999) water-diluted extracts were mixed with water and $5 \%$ sodium nitrite. After reaction 10\% aluminum chloride and $1 \mathrm{~mol} \mathrm{~L}^{-1}$ sodium hydroxide solutions were added to the tubes and filled with water. A catechin standard solution was used for the calibration curve and read at $510 \mathrm{~nm}$. The results were expressed as $\mathrm{mg}$ of catechin equivalents (CE) $\mathrm{g}^{-1}$ of sample.

The detailed determination of phenolic compounds was performed in the EtOH extract using a HPLC system Waters e2695 Separation Module Alliance equipped with a quaternary solvent pump and an automatic injector. For the detection, a diode array detector (DAD) Waters model 2998 and a fluorescence detector (FLD) Waters model 2475 were used. Acquisition and processing of data were carried out using the Waters Empower $^{\mathrm{TM}} 2$ software (Milford, USA). The method was run after filtering the resuspended extract through a $0.45 \mu \mathrm{m}$ nylon membrane (AllcromPhenomenex, USA) and $10 \mu \mathrm{L}$ were, then, injected in a Gemini NX C-18 column $(150 \mathrm{~mm} \times 4.6 \mathrm{~mm} \times 3 \mu \mathrm{m})$ (Phenomenex, USA), maintained at $40{ }^{\circ} \mathrm{C}$. The mobile phase consisted of a gradient mixture of a solvent $\mathrm{A}$ ( $0.85 \%$ phosphoric acid solution) and solvent B (acetonitrile), with a flow-rate of $0.5 \mathrm{~mL} \mathrm{~min}^{-1}$. The gradient was started with $100 \%$ solvent A and adjusted for $93 \%$ solvent $A$ and $7 \%$ of solvent B in $10 \mathrm{~min} ; 90 \%$ solvent A and $10 \%$ solvent B in $20 \mathrm{~min} ; 88 \%$ solvent A and $12 \%$ solvent B in $30 \mathrm{~min}$; $77 \%$ solvent $A$ and $23 \%$ solvent $B$ in $40 \mathrm{~min}$; $65 \%$ solvent $A$ and $35 \%$ solvent B in $45 \mathrm{~min}$; and $100 \%$ solvent B in 55 min (Natividade, Corrêa, de Souza, Pereira, \& Lima 2013). Standard solutions were injected for identification of the wavelengths in which occurred the absorption and retention time (RT) of the compounds. The FLD detector was used at $280 \mathrm{~nm}$ excitation and $320 \mathrm{~nm}$ emission for identification of benzoic acid and flavanols. The DAD detection was employed in the following wavelengths: $280 \mathrm{~nm}$ for identification of phenolic acids, epicatechin and epigalocatechin, $360 \mathrm{~nm}$ for flavonols and $520 \mathrm{~nm}$ for anthocyanins.

\subsubsection{HPLC standards}

Benzoic and gallic acids standards were purchased from Chem Service (West Chester, USA). Kaempferol-3-O-glucoside, (+)-catechin, cyanidin-3,5-O-diglucoside-chloride (cyanin chloride), cyanidin-3-Oglucoside-chloride (kuromanin chloride), (-)-epicatechin, (-)-epicatechin gallate, (-)-epigallocatechin gallate, isorhamnetin-3-O-glucoside, peonidin-3-O-glucoside chloride, procyanidin A2, procyanidin $\mathrm{B}$, procyanidin B2, and isoquercitrin standards were obtained from Extrasynthese (Genay, France). Chlorogenic acid and $p$-coumaric acid were purchased from Sigma (UK).

\subsection{In vitro antioxidant activity (ORAC and PSC methods)}

The hydrophilic ORAC (oxygen radical absorbance capacity) test (Dávalos, Gómez-Cordovés, \& Bartolomé 2004) was carried out adding potassium phosphate buffer ( $\mathrm{PB} \mathrm{pH}$ 7.4)-diluted samples or Trolox standard solutions, to black microplates. Fluorescein and AAPH solutions were briefly added and the microplate reader set with fluorescent filters at $485 \mathrm{~nm}$ for excitation wavelength and $520 \mathrm{~nm}$ for emission wavelength performed 81 reads in $80 \mathrm{~min}$. The ORAC values were expressed as $\mu$ mol Trolox equivalent (TE) by using the trolox standard curves for every microplate assay. The linearity between the net area under the curve and the concentration was checked for the samples and the fluorescence readings were used to the appropriate calculations.

Antioxidant activities of extracts were also determined according to the PSC assay (Peroxyl Radical Scavenging Capacity) described previously (Adom \& Rui 2005). Just prior the use in the reaction, $107 \mu \mathrm{L}$ of $2.48 \mathrm{mmol} \mathrm{L}^{-1}$ dichlorofluorescein diacetate (DCFH-DA) was hydrolyzed to dichlorofluorescein with $893 \mu \mathrm{L}$ of $1.0 \mathrm{mmol} \mathrm{L}^{-1} \mathrm{KOH}$ for 5 $\mathrm{min}$ in a vial to remove the diacetate moiety and then diluted with $7 \mathrm{~mL}$ 
of $75 \mathrm{mmol} \mathrm{L}^{-1}$ phosphate buffer (pH 7.4). The $200 \mathrm{mmol} \mathrm{L}^{-1} 2,2^{\prime}$ azobis(amidinopropane) (ABAP) was freshly prepared in the buffer and kept at $4{ }^{\circ} \mathrm{C}$. In an assay, $100 \mu \mathrm{L}$ of extracts were diluted in $75 \mathrm{mmol} \mathrm{L}^{-1}$ phosphate buffer ( $\mathrm{pH} 7.4$ ) and then transferred into cells on a 96-well plate, and $100 \mu \mathrm{L}$ of dichlorofluorescein was added. The 96-well plate was loaded into the Fluoroskan Ascent fluorescence spectrophotometer (Thermo Labsystems, Franklin, MA) and the solution in each cell was mixed by shaking at $1200 \mathrm{rpm}$ for $20 \mathrm{~s}$. The reaction was then initiated by adding $50 \mu \mathrm{L}$ ABAP from the autodispenser on the equipment. Each set of dilutions for a replicate and control was analyzed three times in adjacent columns. The reaction was carried out at $37^{\circ} \mathrm{C}$, and fluorescence was monitored at $485 \mathrm{~nm}$ excitation and $538 \mathrm{~nm}$ emission with the fluorescence spectrophotometer. Data were acquired with Ascent software, version 2.6 (Thermo Labsystems, Franklin, MA). The areas under the average fluorescence - reaction time kinetic curve (AUC) for both control and samples (up to $36 \mathrm{~min}$ ) were integrated and used as the basis for calculating antioxidant activity according to the equation:

PSC unit $=1-(\mathrm{SA} / \mathrm{CA})$

where SA is AUC for sample or standard dilution and CA is AUC for the control reaction using only buffer. Compounds inhibiting the oxidation of dichlorofluorescein produced smaller SA and higher PSC units. The median effective concentration $\left(\mathrm{EC}_{50}\right.$ ) was defined as the dose required to cause a 50\% inhibition (PSC unit 0.5) for extract. Results were expressed as micromoles of vitamin $\mathrm{C}$ equivalents per micromole of gram of sample.

\subsection{Cell culture}

The human liver $\mathrm{HepG}_{2}$ tumoral cells were grown in Complete Medium (WME supplemented with 5\% FBS, $10 \mathrm{mmol} \mathrm{L}^{-1}$ Hepes, 2 mmol L ${ }^{-1}$ L-glutamine, $5 \mu \mathrm{g} \mathrm{mL}^{-1}$ insulin, $0.05 \mu \mathrm{g} \mathrm{mL}^{-1}$ hydrocortisone, $50 \mathrm{U} \mathrm{mL}^{-1}$ penicillin, $50 \mu \mathrm{g} \mathrm{mL}^{-1}$ streptomycin, and $100 \mu \mathrm{g} \mathrm{mL}^{-1}$ gentamycin) and were maintained at $37^{\circ} \mathrm{C}$ and $5 \% \mathrm{CO}_{2}$ as described previously (Liu et al. 2015).

\subsubsection{Cytotoxicity}

Cytotoxicity was measured toward HepG2 cells using the method developed in our laboratory (Chu, Sun, Wu, \& Liu 2002). The HepG2 cells in growth medium were placed in each well of a 96 -well flatbottom plate at a density of $2.5 \times 10^{4}$ cells well $^{-1}$. After $24 \mathrm{~h}$ of incubation at $37^{\circ} \mathrm{C}$ with $5 \% \mathrm{CO}_{2}$, the growth medium was removed, each well washed with $100 \mu \mathrm{L}$ of phosphate buffer saline (PBS), and replaced by medium containing different concentrations of sample tested (1, 5 , $10,20,30,40$ and $50 \mathrm{mg} \mathrm{mL}^{-1}$ of red-jambo peel). Control cultures received the extraction solution minus the extracts, and blank wells contained $100 \mu \mathrm{L}$ of growth medium with no cells. After another $24 \mathrm{~h}$ of incubation, cytotoxicity was determined by the methylene blue assay (Felice, Sun, \& Liu 2009). Cytotoxicity was determined for each concentration by a $10 \%$ reduction in the absorbance compared to the control. Cytotoxicity was determined from the absorbance at the $570 \mathrm{~nm}$ reading for each concentration compared to the control. A minimum of three replications for each sample was used. The median cytotoxic concentration $\left(\mathrm{CC}_{50}\right)$ was calculated for each sample, which indicates the $50 \%$ cytotoxic concentration of the samples (Felice et al. 2009).

\subsubsection{Cellular antioxidant activity (CAA)}

A $200 \mathrm{mmol} \mathrm{L}^{-1}$ stock solution of DCFH-DA in methanol was prepared, aliquoted, and stored at $-20^{\circ} \mathrm{C}$ until use as described previously by our laboratory (Wolfe \& Rui 2007). A $200 \mathrm{mmol} \mathrm{L}^{-1}$ ABAP stock solution was prepared in water, aliquoted, and stored at $-40{ }^{\circ} \mathrm{C}$ until use. Quercetin solutions were prepared in dimethyl sulfoxide before further dilution in treatment medium (WME with $2 \mathrm{mmol} \mathrm{L}^{-1} \mathrm{~L}$ - glutamine and $10 \mathrm{mmol} \mathrm{L}^{-1}$ Hepes).

The CAA was determined using the protocol described previously (Wolfe et al. 2008; Wolfe \& Rui 2007). Briefly, HepG2 cells were seeded at a density of $6 \times 10^{4}$ well $^{-1}$ on a 96-well microplate in $100 \mu \mathrm{L}$ of complete medium well ${ }^{-1}$. Twenty-four hours after seeding, the growth medium was removed, and the wells were washed with $100 \mu \mathrm{L}$ of PBS. Wells were then treated with $100 \mu \mathrm{L}$ of treatment medium containing solvent control, control extracts, or tested extracts plus $25 \mu \mathrm{mol} \mathrm{L}^{-1}$ DCFH-DA for $1 \mathrm{~h}$. After $1 \mathrm{~h}$, the media was removed, the cells were washed with $100 \mu \mathrm{L}$ of PBS, and $600 \mu \mathrm{mol} \mathrm{L}^{-1} \mathrm{ABAP}$ was applied to the cells in $100 \mu \mathrm{L}$ of oxidant treatment medium (HBSS with $10 \mathrm{mmol} \mathrm{L}^{-1}$ Hepes). The 96-well microplate was placed into a Fluoroskan Ascent FL plate reader at $37^{\circ} \mathrm{C}$. Emission at $538 \mathrm{~nm}$ was measured after excitation at $485 \mathrm{~nm}$ every $5 \mathrm{~min}$ for $1 \mathrm{~h}$.

After blank subtraction and subtraction of the initial fluorescence values, the area under the curve for fluorescence versus time was integrated to calculate the CAA value at each concentration of fruit extract as:

CAA unit $=100-\left(\int \mathrm{SA} / \int \mathrm{CA}\right) \times 100$

where $\int \mathrm{SA}$ is the integrated area under the sample fluorescence versus time curve, and $\int \mathrm{CA}$ is the integrated area from the control curve. The median effective dose $\left(\mathrm{EC}_{50}\right)$ was defined as the dose required to cause a $50 \%$ inhibition of cell proliferation.

$\left(\mathrm{EC}_{50}\right)$ was determined for the sample extracts from the median effect plot of $\log (f a / f u)$ versus $\log ($ dose), where $f a$ is the fraction affected (CAA unit), and $f u$ is the fraction unaffected (1-CAA unit) by the treatment. The $\mathrm{EC}_{50}$ values were stated as the mean $\pm \mathrm{SD}$ for triplicate sets of data obtained from the same experiment. $\mathrm{EC}_{50}$ values were converted to CAA values, which are expressed as $\mu$ mol of quercetin equivalents $(\mathrm{QE})$ per $100 \mathrm{~g}$ of the peel flour, using the mean $\mathrm{EC}_{50}$ value for quercetin from at least four separate experiments.

\subsubsection{Measurement of inhibition of HepG2 cell proliferation}

Methylene blue colorimetric method was adopted to study the antiproliferative effects of red-jambo peel toward HepG2 human tumoral cells (Yang \& Liu 2009). Briefly, HepG2 cells were maintained in WME containing $10 \mathrm{mM}$ Hepes, $5 \mu \mathrm{g} \mathrm{mL}^{-1}$ insulin, $2 \mu \mathrm{gL}^{-1}$ glucagon, 0.05 $\mu \mathrm{g} \mathrm{mL}^{-1}$ hydrocortisone, and $5 \%$ fetal bovine serum. HepG2 cells were maintained at $37^{\circ} \mathrm{C}$ in $5 \% \mathrm{CO}_{2}$ in an incubator. A total of $2.5 \times 10^{4}$ HepG2 cells in growth media were placed in each well of a 96-well flatbottom plate. After $4 \mathrm{~h}$ of incubation at $37{ }^{\circ} \mathrm{C}$ in $5 \% \mathrm{CO}_{2}$, the growth medium was replaced by media containing different concentrations of fruit extracts. Control cultures received the extraction solution minus the fruit extracts, and blank wells contained $100 \mu \mathrm{L}$ of growth medium with no cells. After $72 \mathrm{~h}$ of incubation, cell proliferation was determined by methylene blue assay (Felice et al. 2009). Cell proliferation was determined from the absorbance reading at $490 \mathrm{~nm}$ for each concentration compared to the control. The antiproliferative activity was expressed as $\mathrm{EC}_{50}$ values. At least three replications for each sample were used to determine the cell proliferation.

\section{Statistical analysis}

The data analysis was performed using Sigma Plot 12.0 (Systat Software Inc. San Jose, CA). The statistical analysis data was expressed as the means \pm standard deviation (SD). The Students' $t$-test was applied to detect significant differences between the values for cell proliferation, cells treated and untreated (control) with extract. Pearson's correlation test was performed to verify the relationship between the phenolic, flavonoid contents and anthocyanins of red-jambo peel with CAA and ORAC assay. $P$-values was considered significantly different when they were lower than 0.05 .

\section{Results and discussion}

\subsection{Red-jambo peel phenolic profile}

The results of total phenolic compounds, flavonoids and 
Table 1

Total phenolic, anthocyanins and flavonoid content and antioxidant activity of freeze-dried red-jambo peel flour.

\begin{tabular}{|c|c|}
\hline Parameters & Values \\
\hline Total phenolic compounds & $3.19 \pm 0.08 \mathrm{mg} \mathrm{GAE} \mathrm{g}^{-1}$ \\
\hline Total flavonoids & $2.09 \pm 0.04 \mathrm{mg} \mathrm{CE} \mathrm{g-}^{\mathrm{C}}$ \\
\hline Total anthocyanins & $223.05 \pm 1.07 \mathrm{mg} \mathrm{C} 3 \mathrm{G} 100 \mathrm{~g}^{-1}$ \\
\hline ORAC & 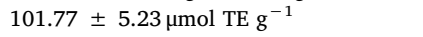 \\
\hline PSC & $\begin{array}{l}1.71 \pm 0.21 \mathrm{mg} \text { of vitamin } \mathrm{C} \text { equivalents } \\
\mathrm{g}^{-1}\end{array}$ \\
\hline $\begin{array}{l}{ }^{\mathrm{a}} \mathrm{CAA} \text { ( } \mu \text { mol of quercetin } \\
\text { equivalents) }\end{array}$ & $66.44 \pm 6.37 \mathrm{~g}^{-1}$ \\
\hline${ }^{\mathrm{b}} \mathrm{CC}_{50}\left(\mathrm{mg} \mathrm{mL}^{-1}\right)$ & $>50$ \\
\hline
\end{tabular}

Data are expressed as mean values $\pm \mathrm{SD}(N=3)$. GAE, Gallic acid equivalents; $\mathrm{CE}$, Catechin equivalents; C3G, cyanidin-3-O-glucoside; TE, Trolox equivalent; PSC, peroxyl radical scavenging capacity; ORAC, oxygen radical absorbance capacity.

a Cellular Antioxidant Activity.

b The $\mathrm{CC}_{50}$ value represents the concentration of red-jambo peel extract in which increases in $50 \%$ cytotoxicity.

anthocyanins from red-jambo peel are shown in Table 1. The presence of phenolics in plants and fruits is correlated to their antioxidant capacity (Leite-Legatti et al. 2012; Lewandowska et al. 2016; Roleira et al. 2015). This is the first study characterizing an ethanolic extract (considered as GRAS - generally recognized as safe) from red-jambo peel, for application in cellular assays.

The ethanolic extract showed similar concentrations of total phe-

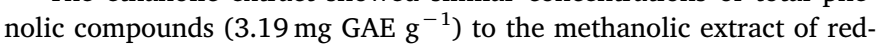
jambo peel published previously (Batista et al. 2017). The red-jambo peel have greater amounts of total phenolic compounds in comparison to the pulp (Batista et al. 2017), and that is why the peel of the fruit is the target of the present study.

Peel and seeds of fruits, generally discarded during processing, concentrates great amounts of glycosylated (poly)phenols as result of defense mechanisms of the plant (Batista et al. 2017; Pereira, Barbosa, Ribeiro Da Silva, Ferri, \& Santos 2017). Despite of the red-jambo peel, our research group has highlighted some fruit by-products with good potential to prevent non-communicable diseases (Batista et al. 2016; da Silva et al. 2017; Leite-Legatti et al. 2012; Viganó \& Martinez 2015). In relation to the flavonoid contents, our results is also in accordance with the one obtained with methanolic extract of the peel of red-jambo fruit (Batista et al. 2017). However, the total monomeric anthocyanins content (Table 1) was lower than in the methanolic extract of red-jambo

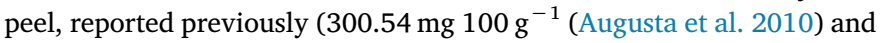

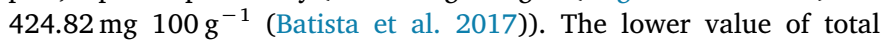
monomeric anthocyanins in this study could be related to additional procedures used after the extraction, such as, evaporation of the solvent and lyophilization.

Regarding the phenolic compounds profile performed by HPLCFLD/DAD, the phenolic acid contents showed in this study were higher than the ones observed in hydrolyzed methanolic extract of peel (Batista et al. 2017); in which the amount of the p-coumaric acid and benzoic acid were around four and two times higher, respectively. We have found gallic acid and chlorogenic acid in the ethanolic extract of red-jambo peel, which have not been identified in the fruit, so far (Table 2).

Proanthocyanidins or condensed tannins were determined in the red-jambo peel by HPLC method (Table 2). The major procyanidins found in the peel of the red-jambo were procyanidin B1, followed by similar amounts of procyanidin B2 and A2, which corroborates previous study with the methanolic extract (procyanidin $\mathrm{B} 1>\mathrm{B} 2>$ procyanidin A2) (Batista et al. 2017).

In relation to the flavonols, we showed similar results to those presented in the literature, in which, the major flavonol present in methanolic extract of red-jambo peel was isorhamnetin-3-O-glucoside
(Batista et al. 2017). We have also found other flavonols: isoquercitin and kaempferol-3-O-glucoside (Table 2), but not rutin, found in other studies (Batista et al. 2017; Reynertson, Yang, Jiang, Basile, \& Kennelly, 2008).

As well as previous study, the flavanols, such as (-)-epicatechin gallate, (+)-catechin, (-)-epicatechin, were also quantified in the ethanolic extract. In addition, we have found the (-)-epigallocatechin gallate compound for the first time in the peel of the red-jambo fruit (Table 2).

Some studies have found anti-tumoral effects against HepG2 human hepatoma cells of such fruit-isolated or commercially available phenolic compounds (chlorogenic acid quercetin, isoquercetrin, (+)-catechin (-)-epicatechin) (Haza, 2008; He, Liu \& Rui, 2008). The same phenolic compounds were also present in red-jambo peel ethanolic extract, corroborating our results (section 4.3).

Results showed that anthocyanins were the major class of phenolic compounds in the peel of red-jambo fruit determined by HPLC using the ethanolic extract. The major anthocyanins identified were cyanidin-3$O$-glucoside, followed by cyanidin-3,5-O-glucoside and peonidin-3-Oglucoside (Table 2). The red-jambo methanolic extract performed in previous studies also highlighted anthocyanins as the major phenolic compound group in the peel part of the fruit (Batista et al. 2017; Nunes et al. 2016). However, the values for the three anthocyanins found were higher in our ethanolic extract than in the methanolic extract as shown by the studies cited above. Ethanol is a good solvent for extracting sugars, as the anthocyanins in the red-jambo peel were glycosylated, the extraction of these compounds were then facilitated.

The anthocyanin composition of red-jambo fruit peel incites researches using its extracts as cancer prevention therapy. Studies have been highlighting the effects of an anthocyanin-rich extract against liver tumoral cell lines and hepatocarcinogenesis in rats (Bishayee et al. 2010; Shin et al. 2009). These authors and others (Leite-Legatti et al. 2012; L.-S. Wang \& Stoner 2008) pointed out anthocyanin-rich extracts as powerful free-radical scavengers, besides of their effects on activating phase II enzymes, anti-cell proliferation, induction of apoptosis, and anti-inflammatory effects, being recommended for cancer prevention (L.-S. Wang \& Stoner 2008).

\subsection{Total antioxidant capacity}

Natural antioxidants are known for their antioxidant capacity and action in metabolic pathways, bringing health benefits (Shahidi \& Ambigaipalan 2015). There is a range of methods used to evaluated antioxidant capacity of compounds. However, phytochemicals have complex reactivity, thus, is necessary at least two methods to assess the antioxidant capacity of extracts or food extracts in order to provide reliability (Altemimi, Lakhssassi, Baharlouei, Watson, \& Lightfoot 2017). Therefore, the antioxidant activity of red-jambo peel extract was conducted using three different methods: PSC, ORAC and CAA.

The PSC and ORAC values for the red-jambo peel were $1.71 \mathrm{mg}$ of vitamin $C$ equivalents $\mathrm{g}^{-1}$ and $107.76 \mu \mathrm{mol} \mathrm{TE} \mathrm{g}^{-1}$, respectively. Our PSC value was similar to results found for blueberries (Vaccinium spp.) (H. Wang et al. 2017) and grapes (V. vinifera) (Liang, Cheng, Zhong, \& Liu 2014). The ORAC value of the red-jambo peel extracted with ethanol was higher than the ones shown for blueberries, red grape and apple (26.27, 26.05 and $45.92 \mu \mathrm{mol} \mathrm{TE} \mathrm{g}^{-1}$, respectively) (Liang et al. 2014; H. Wang et al. 2017). Based on these data we can conclude that red-jambo peel have high antioxidant activity, as comparable to those fruits, well known by their antioxidant capacity.

The ORAC values were highly correlated with total anthocyanins $\left(\mathrm{r}^{2}\right.$ $=0.99$ ), but the same pattern was not observed for the total phenolics $\left(r^{2}=0.7\right)$ and flavonoids $\left(r^{2}=0.67\right)$. These results are not consistent with others reports in the scientific literature for other extracts with stronger correlation between ORAC and phenolic compounds (Liang et al. 2014; H. Wang et al. 2017). Many times, the discrepancy at comparing antioxidant capacity tests and the total polyphenol content 
Table 2

(Poly)phenols of freeze-dried red-jambo peel analyzed by HPLC-DAD/FLD.

\begin{tabular}{|c|c|c|c|c|}
\hline & Wavelength (DAD) or emission/excitation (FLD) & $\mathrm{RT}$ (min) & Compound & $\mathrm{mg} 100 \mathrm{~g}^{-1}$ of peel \\
\hline 1 & $280 \mathrm{~nm}$ & $26.14 \pm 0.011$ & Chlorogenic acid & $0.37 \pm 0.06$ \\
\hline 2 & $280 \mathrm{~nm}$ & $37.22 \pm 0.015$ & $p$-Coumaric acid & $0.41 \pm 0.001$ \\
\hline 3 & $320 \mathrm{~nm} / 280 \mathrm{~nm}$ & $25.55 \pm 0.014$ & Benzoic acid & $0.65 \pm 0.001$ \\
\hline 4 & $280 \mathrm{~nm}$ & $42.79 \pm 0.001$ & (-)-Epicatechin gallate & $1.63 \pm 0.11$ \\
\hline 5 & $280 \mathrm{~nm}$ & $29.46 \pm 0.342$ & (-)-Epigallocatechin gallate & $0.53 \pm 0.05$ \\
\hline 6 & $280 \mathrm{~nm}$ & $11.02 \pm 0.001$ & Gallic acid & $0.20 \pm 0.06$ \\
\hline 7 & $320 \mathrm{~nm} / 280 \mathrm{~nm}$ & $24.17 \pm 0.009$ & $(+)$-Catechin & $0.69 \pm 0.05$ \\
\hline 8 & $320 \mathrm{~nm} / 280 \mathrm{~nm}$ & $29.35 \pm 0.008$ & $(-)$-Epicatechin & $2.04 \pm 0.001$ \\
\hline 9 & $320 \mathrm{~nm} / 280 \mathrm{~nm}$ & $44.07 \pm 0.001$ & Procyanidin A2 & $2.45 \pm 0.001$ \\
\hline 10 & $320 \mathrm{~nm} / 280 \mathrm{~nm}$ & $22.52 \pm 0.010$ & Procyanidin B1 & $4.81 \pm 0.001$ \\
\hline 11 & $320 \mathrm{~nm} / 280 \mathrm{~nm}$ & $31.05 \pm 0.317$ & Procyanidin B2 & $0.25 \pm 0.12$ \\
\hline 12 & $360 \mathrm{~nm}$ & $46.57 \pm 0.001$ & Isorhamnetin-3-O-glucoside & $4.60 \pm 0.06$ \\
\hline 13 & $360 \mathrm{~nm}$ & $44.12 \pm 0.002$ & Isoquercitrin & $1.87 \pm 0.001$ \\
\hline 14 & $360 \mathrm{~nm}$ & $46.04 \pm 0.001$ & Kaempferol-3-O-glucoside & $0.57 \pm 0.12$ \\
\hline 15 & $520 \mathrm{~nm}$ & $23.55 \pm 0.022$ & Cyanidin-3,5-O-diglucoside $^{1}$ & $31.33 \pm 0.05$ \\
\hline 16 & $520 \mathrm{~nm}$ & $28.02 \pm 0.021$ & Cyanidin-3-O-glucoside $^{2}$ & $228.91 \pm 1.15$ \\
\hline \multirow[t]{2}{*}{17} & $520 \mathrm{~nm}$ & $35.41 \pm 0.013$ & Peonidin-3-O-glucoside ${ }^{3}$ & $2.53 \pm 0.001$ \\
\hline & SUM & & & $281.63 \pm 1.04$ \\
\hline
\end{tabular}

RT: retention time.

may be due to the interference of other compounds in the Folin-Ciocalteu reaction, as ascorbic acid, sugars and other reducing compounds (Rezaire et al. 2014). Thus, in red-jambo fruit peel the anthocyanins could be cited the major contributors to the scavenge power against peroxyl radical, proved by the ORAC assay. Anthocyanins have shown to be potent antioxidant and free radical scavengers due to presence of hydroxyl groups $(\mathrm{OH})$ mainly in the $3^{\prime}$ - and 5 '-position in the B ring (Onzalo \& Eresa 2004).

\subsubsection{Cellular antioxidant activity (CAA)}

The cellular antioxidant activity of red-jambo peel was measured using the CAA assay. The CAA test was performed using extract concentrations $\leq 30 \mathrm{mg} \mathrm{mL}^{-1}$ of red-jambo peel which did not show cytotoxicity to cells $\left(0.5-30 \mathrm{mg} \mathrm{mL}^{-1}\right.$ of red-jambo peel; $0.00195-0.117 \mathrm{mg}$ of phenolics $\mathrm{mL}^{-1}$; or $0.00111-0.0669 \mathrm{mg}$ of anthocyanins $\mathrm{mL}^{-1}$ ).The CAA assay provides a better understanding of phytochemicals dynamic than the traditional methods (Wolfe \& Rui 2007). This assay addresses the complexity of the biological system including some issues of metabolism, such as uptake and distribution (Wolfe \& Rui 2007).

The CAA value for red-jambo peel was $66.44 \mu \mathrm{mol}$ quercetin equivalents $100 \mathrm{~g}^{-1}$ of sample. The $\mathrm{EC}_{50}$ for CAA was $3.99 \mathrm{mg} \mathrm{mL}^{-1}$ (Table 2). Our CAA data was higher than the values shown by some red grapes samples, ranging from 5.3 to $59.7 \mu \mathrm{mol}$ quercetin equivalents $100 \mathrm{~g}^{-1}$ of sample. In addition, the CAA value of red-jambo peel was similar to values found for two cranberry varieties (Bluecrop, 68.1 $7 \mu \mathrm{mol}$ quercetin equivalents $100 \mathrm{~g}^{-1}$ and Primary operation blue, $60.67 \mu \mathrm{mol}$ quercetin equivalents $100 \mathrm{~g}^{-1}$ ), but not to the 12 other varieties (Liang et al. 2014). The CAA value of red-jambo peel was found greater than the value found for apple $(28.1 \mu \mathrm{mol}$ quercetin equivalents $100 \mathrm{~g}^{-1}$ ) (Wolfe \& Rui 2007).

The CAA values were significantly and positively $(p<0.05)$ correlated with phenolic contents $\left(r^{2}=0.89\right)$, as well as the flavonoids $\left(r^{2}=0.91\right)$ and the anthocyanins $\left(r^{2}=0.96\right)$. Anthocyanins showed higher correlation with CAA than total phenolic compounds, being the most influent antioxidant of the phenolic classes, corroborating the ORAC value correlation. However, the correlation coefficients of the CAA values to the total phenolics, total flavonoids and anthocyanins were higher when compared to the ORAC value. These results showed CAA assay, in our extract, as a better method to predict cellular antioxidant activity of those phytochemicals than ORAC assay.

Cyanidin-3-O-glucoside, cyanidin-3,5- $O$-diglucoside and peonidin3-O-glucoside, the main anthocyanins found in the red-jambo peel have been shown antioxidant capacity due to the $\mathrm{OH}$ functional radicals in previous studies (Onzalo \& Eresa 2004; Teng et al. 2017). In addition, glucosylation of anthocyanins affect the antioxidant capacity as shown by cyanidin (Fukumoto \& Mazza 2000).

Besides the presence of anthocyanins, the peel of red-jambo showed other phenolic compounds, like phenolic acids and other flavonoids, significantly and positively correlated to the CAA value. Chlorogenic acid and $p$-Coumaric acid, phenolic acids can transfer a hydrogen or eletron from their $\mathrm{OH}$ group to radicals, neutralizing their effect (Lópezmartínez, Santacruz-ortega, \& Navarro 2015). In addition to these mechanisms, phenolic compounds have been proved to increase antioxidant cell system, activating transcription factors, such as nuclear factor [erythroidderived 2]-like 2 (NRF2), the antioxidant response element (ARE), which plays an important role in cellular antioxidant defenses. ARE is a regulatory element of genes encoding antioxidant proteins and phase II detoxification enzymes, such as glutathionetransferases, $\mathrm{NAD}(\mathrm{P}) \mathrm{H}$ : quinone oxidoreductase 1 (NOO1) and dihydronicotinamide riboside (NRH): quinone oxidoreductase 2 (NQO2), which are crucial to oxidative stress control (Hwang \& Lee 2017; Zhang et al. 2017). Furthermore, such compounds also can decrease inflammatory pathways activation (nuclear factor NF kB and activator protein 1), also responsible for the increase of ROS production. All these factors together can decrease ROS concentration in the cell leading to increase of antioxidant activity as demonstrated by our results after extract administration in cell culture (Arulselvan et al. 2016). An antioxidant system increased can prevent the overproduction of the reactive species and related diseases, such cancer (Ye et al. 2015).

\subsection{Inhibition of human hepatoma cell proliferation}

Antioxidants have ability to scavenge free radicals, counteract DNA damage and subsequent mutation (Pisoschi \& Pop 2015). The DNA damage have been considered a first step for human cancer initiation (Lord \& Ashworth 2012). The consumption of fruit and vegetables, rich in antioxidant compounds are associated to reduced risk of cancer (R. H. Liu 2004). Therefore, red-jambo peel was administrated in human liver HepG2 tumoral cells to determine if the extracts could inhibit tumor cell proliferation. The antiproliferative ability of the peel was not investigated previously. Thus, our study provides important information, which, in the future, could be used as an alternative therapy to the prevention and tumor development control.

The HepG2 tumoral cells were treated with extracts equivalent to 1 to $50 \mathrm{mg} \mathrm{mL}^{-1}$ of the red-jambo peel for $72 \mathrm{~h}$. The ethanolic extract of red-jambo peel had a potent inhibitory effect on the HepG2 cell growth and proliferation (Fig. 1). The $\mathrm{EC}_{50}$ for the red-jambo peel ethanolic extract was $40.92 \mathrm{mg} \mathrm{mL}^{-1}$ and the lower the values of $\mathrm{EC}_{50}$, the higher 


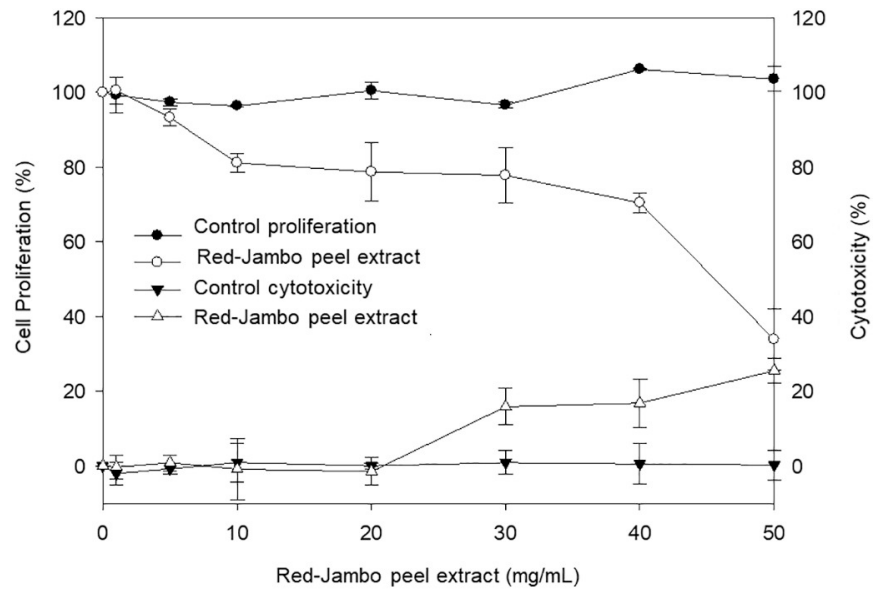

Fig. 1. Dose-response curve of antiproliferative activity and cytotoxicity toward HepG2 human liver tumoral cells by red-jambo peel extract. EC $_{50}$ means values $\pm \operatorname{SD}(n=3)$. The cells were treated at the concentrations $1,5,10,20$, 30,40 and $50 \mathrm{mg}$ of red-jambo peel $\mathrm{mL}^{-1}$. (For interpretation of the references to colour in this figure legend, the reader is referred to the web version of this article.)

antiproliferative activities. Our result was similar to the one found for apples (49.4 $\mathrm{mg} \mathrm{mL}^{-1}$ ), but higher inhibition of tumor cell proliferation when compared to strawberry and red grape $\left(56.3 \mathrm{mg} \mathrm{mL}^{-1}\right.$ and $71.0 \mathrm{mg} \mathrm{mL}^{-1}$, respectively). A previous digestion of the sample before cell treatment could increase absorption of polyphenols, reaching higher amounts of phenolic compounds or their metabolites in the circulatory system compared to undisgested ones. Anthocyanins, the major class of phenolic compounds found in the Red-jambo, has low bioavailability $(<1 \%)$, but several studies have reported that they show important health-promoting effects even in low concentrations (Kamiloglu et al. 2017; Kamiloglu, Capanoglu, Grootaert, \& van Camp 2015).

No significantly correlations were found between the antiproliferative activity against the HepG2 liver tumoral cells and the total phenolic, flavonoids and anthocyanins values $(p>0.05)$. Such results were consistent with what were previously reported in literature (Chu et al. 2002), suggesting that specific phytochemical, or even synergy action have more influence in the antiproliferative activities then total phytochemicals (Liang et al. 2014). Others phenolic compounds found in red-jambo peel such as, chlorogenic acid, $p$-coumaric acid, gallic acid, (+)-catechin, (-)-epicatechin and also proanthocyanidins have demonstrated directly action in proteins that control tumoral cellular life cycle (cell division and apoptosis) or DNA repair and angiogenesis. (Battaglini et al. 2017; Kwon, Lambert, Yang, \& Hong 2015; J. Liu et al. 2015; Lu et al. 2010).

Chlorogenic acid is an effective chemopreventive agent for HepG2 cells, leading to cell cycle arrest at the $S$ phase in HepG2 cells and HepG2 xenografts in nude mice in a concentration-denpendent manner. Chlorogenic acid also induced the activation of extracellular-signalregulated kinase $1 / 2(\mathrm{ERK} 1 / 2)$ and decrease the expression of matrix metalloproteinases associated with degradation of the extracellular matrix linked to invasion and metastasis (Yan, Liu, Hou, Dong, \& Li 2017). P-coumaric acid reduces expression of vascular endothelial growth fator (VEGF) and basic fibroblast growth factor (bFGF), both are angiogenic factors that stimulates the permeability, proliferation, migration and tube formation of endothelial cells demonstrating chemopreventive effect of this compounds. Furthermore, such compound can increased levels of proteins involved in mitochondria apoptosis (Ccaspase 9, C-caspase 3, bcl-2, bcl-xs and myeloid cell leukaemia-1) (Yan et al. 2017).

Gallic acid has been shown to suppress carcinogenesis in animal models and in vitro tumoral cells lines, acting in a range of signaling pathway relation to cell cycle, metastasis, angiogenesis and apoptosis. This compound induces G1 phase arrest through ATM- cyclin-dependent kinase 2 (Chk2) activation influencing the induction of apoptosis and regulation of DNA damage dependent checkpoints (Yan et al. 2017); decrease the ribonucleotide reductase (RR) activity, significantly increased in malignant tumors cells. RR is linked to DNA synthesis in rapidly growing tumor and gallic acid is able to cell cycle perturbation and induction of apoptosis; inhibit cyclooxygenase 2 (COX-2), in tumoral cells COX-2 overexpression makes cells resistant to apoptotic stimuli; decreased of endothelial cell proliferation, critical step in angiogenesis, cell migration and proliferation through VEGF expression decrease. Thus, all of these gallic acid performances can be understood as a cancer chemoprevention (Verma, Singh, \& Mishra 2013).

Catechin and epicatechin can lower cancer cells lines proliferation through VEGF expression reduce with regulation of angiogenisis (Verma et al. 2013). Furthermore, can also modulated cell cycle regulatory proteins (cyclins, cyclin-dependent kinases [CDK], CDK inhibitors) and inhibited TNF $\alpha$ - that increases tumoral cells invasion and metastasis (Verma et al. 2013). Proanthocyanidins decrease tumoral cell proliferation in vitro and in vivo using a tumor xenograft model. Proanthocyanidins decrease VEGF and CD31 (a marker of neovascularization) expression in cells of non-small cell lung cancer, leading to cell proliferation decline. Proanthocyanidins lower tumor volume in xenograft model in a concentration-denpendent manner which was associated with the: enhancement in the levels of insulin-like growth factor binding protein-3 (IGFBP-3) in both tumor microenvironment and plasma, lower levels of IGFBP-3 are linked to increased risk of malignancy; inhibition of angiogenic factors and induction of apoptosis of the tumor cells (Akhtar, Meeran, Katiyar, \& Katiyar 2009).

Therefore, the antiproliferative effect of red-jambo peel could be due to the availability of a single phenolic compound cited above or even by the synergism among them. Studies have shown that the synergism effect among some phenolic compounds have a stronger effect on decrease of tumoral cells proriferation or in a xenograft model of cancer than isolated compounds (Burgio, Lopomo, \& Migliore 2015).

In summary, the results of our investigation demonstrated for the first time the ability of red-jambo peel ethanolic extract to decrease HepG2 (human hepatoma) cell line proliferation and growth. Furthermore, we also observed expressive amounts of anthocyanins as well as detection of new other compounds in the ethanolic extract, not found previously in a methanolic extraction. All these findings indicate the ethanolic extract from red-jambo peel as a therapeutic alternative for preventing tumoral cell growth and proliferation, acting as -chemopreventive extract in in vivo models. Future investigations on the mechanism of action of the bioactive compounds from red-jambo peel should be performed in order to promote the use of the derived ethanolic extract.

\section{Acknowledgments}

The authors are grateful to National Counsel of Technological and Scientific Development, Brazil (CNPq) (301108/2016-1); CAPES, Brazil for financial support and São Paulo Research Foundation, Brazil (FAPESP) COBRA (2015/50333-1).

\section{References}

Adom, K. K., \& Rui, H. L. (2005). Rapid peroxyl radical scavenging capacity (PSC) assay for assessing both hydrophilic and lipophilic antioxidants. Journal of Agricultural and Food Chemistry, 53(17), 6572-6580. https://doi.org/10.1021/jf048318o.

Akhtar, S., Meeran, S. M., Katiyar, N., \& Katiyar, S. K. (2009). Cancer Therapy: Preclinical Grape seed Proanthocyanidins Inhibit the growth of Human Non-Small Cell Lung Cancer Xenografts byT argeting Insulin-like growth factor Binding Protein-3. Tumor Cell Proliferation and Angiogenic Factors, 15(3), 821-832. https://doi.org/10.1158/ 1078-0432.CCR-08-1901.

Altemimi, A., Lakhssassi, N., Baharlouei, A., Watson, D., \& Lightfoot, D. (2017) Phytochemicals: Extraction, Isolation, and Identification of Bioactive Compounds from Plant Extracts. Plants, 6(4), 42. https://doi.org/10.3390/plants6040042. 
Arulselvan, P., Fard, M. T., Tan, W. S., Gothai, S., Fakurazi, S., Norhaizan, M. E., \& Kumar, S. S. (2016). Role of antioxidants and natural products in inflammation. 2016https://doi. org/10.1155/2016/5276130.

Augusta, I. M., Resende, J. M., Borges, S. V., Maia, M. C. A., \& Couto, M. A. P. G. (2010). Caracterização física e química da casca e polpa de jambo vermelho (Syzygium malaccensis, (L.) Merryl \& Perry). Ciência e Tecnologia de Alimentos, 30(4), 928-932. https://doi.org/10.1590/S0101-20612010000400014.

Batista, Â. G., da Silva, J. K., Betim Cazarin, C. B., Biasoto, A. C. T., Sawaya, A. C. H. F., Prado, M. A., \& Maróstica Júnior, M. R. (2017). Red-jambo (Syzygium malaccense): Bioactive compounds in fruits and leaves. LWT - Food Science and Technology, 76, 284-291. https://doi.org/10.1016/j.lwt.2016.05.013.

Batista, Â. G., Ferrari, A. S., Da Cunha, D. C., Da Silva, J. K., Cazarin, C. B. B., Correa, L. C., ... Maróstica Júnior, M. R. (2016). Polyphenols, antioxidants, and antimutagenic effects of Copaifera langsdorffii fruit. Food Chemistry, 197, 1153-1159. https://doi. org/10.1016/j.foodchem.2015.11.093.

Battaglini, M., Berger, L., Giannaccini, M., Dente, L., Hampel, S., Vittorio, O., \& Raffa, V. (2017). European Journal of Pharmaceutics and Biopharmaceutics a catechin nanoformulation inhibits WM266 melanoma cell proliferation, migration and associated neo-angiogenesis. European Journal of Pharmaceutics and Biopharmaceutics, 114, 1-10. https://doi.org/10.1016/j.ejpb.2016.12.024.

Bishayee, A., Haznagy-Radnai, E., Mbimba, T., Sipos, P., Morazzoni, P., Darvesh, A. S., .. Hohmann, J. (2010). Anthocyanin-rich black currant extract suppresses the growth of human hepatocellular carcinoma cells. Natural Product Communications, 5(10), $1613-1618$.

Bueno, J. M., Ramos-Escudero, F., Sáez-Plaza, P., Muñoz, A. M., José Navas, M., \& Asuero, A. G. (2012). Analysis and Antioxidant Capacity of Anthocyanin Pigments. Part I: General Considerations concerning Polyphenols and Flavonoids. Critical Reviews in Analytical Chemistry, 42(2), 102-125. https://doi.org/10.1080/10408347.2011. 632312.

Burgio, E., Lopomo, A., \& Migliore, L. (2015). Obesity and diabetes: From genetics to epigenetics. Molecular Biology Reports, 42(4), 799-818. https://doi.org/10.1007/ s11033-014-3751-Z.

Chu, Y. F., Sun, J., Wu, X., \& Liu, R. H. (2002). Antioxidant and antiproliferative activities of common vegetables. Journal of Agricultural and Food Chemistry, 50(23), 6910-6916. https://doi.org/10.1021/jf020665f.

Dávalos, A., Gómez-Cordovés, C., \& Bartolomé, B. (2004). Extending Applicability of the Oxygen Radical Absorbance Capacity (ORAC-Fluorescein) Assay. Journal of Agricultural and Food Chemistry, 52(1), 48-54. https://doi.org/10.1021/jf0305231.

Felice, D. L., Sun, J., \& Liu, R. H. (2009). A modified methylene blue assay for accurate cell counting. Journal of Functional Foods, 1(1), 109-118. https://doi.org/10.1016/j. iff.2008.09.014.

Fukumoto, L. R., \& Mazza, G. (2000). Assessing antioxidant and prooxidant activities of phenolic. https://doi.org/10.1021/jf000220w.

Haza, A. I. (2008). Dietary polyphenols protect against $N$-nitrosamines and benzo (a) pyrene-induced DNA damage (strand breaks and oxidized purines/pyrimidines) in HepG2 human hepatoma cells. European Journal of Nutrition, 47, 479-490. https:// doi.org/10.1007/s00394-008-0751-6.

He, X., Liu, D., \& Rui, H. L. (2008). Sodium borohydride/chloranil-based assay for quantifying total flavonoids. Journal of Agricultural and Food Chemistry, 56(20), 9337-9344. https://doi.org/10.1021/jf070954+.

Hwang, Y. S. J., \& Lee, K. C. J. (2017). Original research article a phenolic acid and flavonoid fraction isolated from lolium multiflorum lam. Prevents D -Galactosamineinduced liver damages through the augmentation of Nrf2 expression. Indian Journal of Clinical Biochemistry. https://doi.org/10.1007/s12291-017-0714-x.

Kamiloglu, S., Capanoglu, E., Grootaert, C., \& van Camp, J. (2015). Anthocyanin absorption and metabolism by human intestinal Caco-2 cells-A review. International Journal of Molecular Sciences, 16(9), 21555-21574. https://doi.org/10.3390/ ijms160921555.

Kamiloglu, S., Grootaert, C., Capanoglu, E., Ozkan, C., Smagghe, G., Raes, K., \& Van Camp, J. (2017). Anti-inflammatory potential of black carrot (Daucus carota L.) polyphenols in a co-culture model of intestinal Caco-2 and endothelial EA.hy926 cells. Molecular Nutrition \& Food Research, 61(2), 1-11. https://doi.org/10.1002/ mnfr.201600455.

Kumar, S., Gautam, S., \& Sharma, A. (2013). Identification of Antimutagenic Properties of Anthocyanins and Other Polyphenols from Rose (Rosa centifolia) Petals and Tea. Journal of Food Science, 78(6), 948-954. https://doi.org/10.1111/1750-3841.12135.

Kwon, S. J., Lambert, J. D., Yang, C. S., \& Hong, J. (2015). Role of reactive oxygen species from the green tea catechin, (-) -epigallocatechin-3-gallate in growth modulation of intestinal cells. 24(4), 1541-1548. https://doi.org/10.1007/s10068-015-0198-5.

Leite, A. V., Malta, L. G., Riccio, M. F., Eberlin, M. N., Pastore, G. M., \& Maróstica Júnior, M. R. (2011). Antioxidant potential of rat plasma by administration of freeze-dried Jaboticaba peel (Myrciaria Jaboticaba Vell Berg). Journal of Agricultural and Food Chemistry, 59(6), 2277-2283. https://doi.org/10.1021/jf103181x.

Leite-Legatti, A. V., Batista, A. G., Dragano, N. R. V., Marques, A. C., Malta, L. G., Riccio, M. F., ... Maróstica, M. R. (2012). Jaboticaba peel: Antioxidant compounds, antiproliferative and antimutagenic activities. Food Research International, 49(1), 596-603. https://doi.org/10.1016/j.foodres.2012.07.044.

Lewandowska, H., Kalinowska, M., Lewandowski, W., Stepkowski, T. M., \& Brzóska, K. (2016). The role of natural polyphenols in cell signaling and cytoprotection against cancer development. The Journal of Nutritional Biochemistry. https://doi.org/10. 1016/j.jnutbio.2015.11.006.

Liang, Z., Cheng, L., Zhong, G. Y., \& Liu, R. H. (2014). Antioxidant and antiproliferative activities of twenty-four Vitis vinifera grapes. PLoS One, 9(8), https://doi.org/10 1371/journal.pone.0105146.

Liu, J., Bai, J., Jiang, G., Li, X., Wang, J., \& Wu, D. (2015). Anti-Tumor effect of Pinus massoniana bark proanthocyanidins on ovarian cancer through induction of cell apoptosis and inhibition of cell migration. 1-15. https://doi.org/10.1371/journal.pone.0142157.

Liu, R. H. (2004). Potential synergy of phytochemicals in cancer prevention: Mechanism of action. The Journal of Nutrition, 134(12 Suppl), 3479S-3485S. 134/12/3479S (pii).

López-martínez, L. M., Santacruz-ortega, H., \& Navarro, R. (2015). A 1 H NMR Investigation of the Interactions between Phenolic Acids Found in Mango (Manguifera Indicator cv Ataulfo) and Papaya (Carica papaya cv Maradol) and 1, 1-diphenyl- 2picrylhydrazyl (DPPH) Free Radicals, 1-11. https://doi.org/10.1371/journal.pone. 0140242.

Lord, C. J., \& Ashworth, A. (2012). The DNA damage response and cancer therapy. Nature, 481(7381), 287-294. https://doi.org/10.1038/nature10760.

Lu, Y., Jiang, F., Jiang, H., Wu, K., Zheng, X., Cai, Y., ... To, S. T (2010). Gallic acid suppresses cell viability, proliferation, invasion and angiogenesis in human glioma cells. European Journal of Pharmacology, 641(2-3), 102-107. https://doi.org/10. 1016/j.ejphar.2010.05.043.

Matsukawa, T., Inaguma, T., Han, J., Villareal, M. O., \& Isoda, H. (2015). Cyanidin-3glucoside derived from black soybeans ameliorate type 2 diabetes through the induction of differentiation of preadipocytes into smaller and insulin-sensitive adipocytes. The Journal of Nutritional Biochemistry, 26(8), 860-867. https://doi.org/10. 1016/j.jnutbio.2015.03.006.

Natividade, M. M. P., Corrêa, L. C., de Souza, S. V. C., Pereira, G. E., \& Lima, L. C.d. O. (2013). Simultaneous analysis of 25 phenolic compounds in grape juice for HPLC: Method validation and characterization of São Francisco Valley samples. Microchemical Journal, 110, 665-674. https://doi.org/10.1016/j.microc.2013.08. 010.

Nunes, P. C., de Aquino, J., Rockenbach, I. I., \& Stamford, T. L. M. (2016). Physicochemical characterization, bioactive compounds and antioxidant activity of malay apple [Syzygium malaccense (L.) Merr. \& L.M. Perry]. PLoS One, 11(6), https://doi. org/10.1371/journal.pone.0158134 e0158134.

Onzalo, Ä. N. C. R. I., \& Eresa, S. O. D. E. P. A. (2004). Antioxidant and cellular activities of anthocyanins and their corresponding vitisins a s studies in platelets, monocytes, and. 3378-3384. https://doi.org/10.1021/jf035360v.

Pereira, L. D., Barbosa, J. M. G., Ribeiro Da Silva, A. J., Ferri, P. H., \& Santos, S. C. (2017). Polyphenol and Ellagitannin Constituents of Jabuticaba (Myrciaria cauliflora) and Chemical Variability at Different Stages of Fruit Development. Journal of Agricultural and Food Chemistry, 65(6), 1209-1219. https://doi.org/10.1021/acs.jafc.6b02929.

Pisoschi, A. M., \& Pop, A. (2015). The role of antioxidants in the chemistry of oxidative stress: A review. European Journal of Medicinal Chemistry, 97, 55-74. https://doi.org/ 10.1016/j.ejmech.2015.04.040.

Pistollato, F., Giampieri, F., \& Battino, M. (2015). The use of plant-derived bioactive compounds to target cancer stem cells and modulate tumor microenvironment. Food and Chemical Toxicology, 75, 58-70. https://doi.org/10.1016/j.fct.2014.11.004.

Prescott, C., \& Bottle, S. E. (2017). Biological Relevance of Free Radicals and Nitroxides. Cell Biochemistry and Biophysics, 75(2), 227-240. https://doi.org/10.1007/s12013016-0759-0.

Reynertson, K. A., Yang, H., Jiang, B., Basile, M. J., \& Kennelly, E. J. (2008). Quantitative analysis of antiradical phenolic constituents from fourteen edible Myrtaceae fruits. Food Chemistry. https://doi.org/10.1016/j.foodchem.2008.01.021.

Rezaire, A., Robinson, J., Bereau, D., Verbaere, A., Sommerer, N., Khan, M. K., ... FilsLycaon, B. (2014). Amazonian palm Oenocarpus bataua ("patawa"): Chemical and biological antioxidant activity - Phytochemical composition. Food Chemistry, 149, 62-70. https://doi.org/10.1016/j.foodchem.2013.10.077.

Roleira, F. M. F., Tavares-Da-Silva, E. J., Varela, C. L., Costa, S. C., Silva, T., Garrido, J., \& Borges, F. (2015). Plant derived and dietary phenolic antioxidants: Anticancer properties. Food Chemistry, 183, 235-258. https://doi.org/10.1016/j.foodchem. 2015.03.039.

Shahidi, F., \& Ambigaipalan, P. (2015). Phenolics and polyphenolics in foods, beverages and spices: Antioxidant activity and health effects - a review. Journal of Functional Foods, 18, 820-897. https://doi.org/10.1016/j.jff.2015.06.018.

Shin, D. Y., Ryu, C. H., Lee, W. S., Kim, D. C., Kim, S. H., Hah, Y.-S., ... Choi, Y. H. (2009). Induction of apoptosis and inhibition of invasion in human hepatoma cells by anthocyanins from meoru. Vol. 1171Annals of the New York Academy of Scienceshttps://doi.org/ 10.1111/j.1749-6632.2009.04689.x.

da Silva, J. K., Batista, Â. G., Cazarin, C. B. B., Dionísio, A. P., de Brito, E. S., Marques, A. T. B., \& Maróstica Junior, M. R. (2017). Functional tea from a Brazilian berry: Overview of the bioactives compounds. LWT - Food Science and Technology, 76, 292-298. https://doi.org/10.1016/j.lwt.2016.06.016.

Swain, T., \& Hillis, W. E. (1959). The phenolic constituents of Prunus domestica. The quantitative analysis of phenolic constituents. Journal of the Science of Food and Agriculture, 10(1), 63-68. https://doi.org/10.1002/jsfa.2740100110.

Teng, H., Fang, T., Lin, Q., Song, H., Liu, B., \& Chen, L. (2017). Trends in food science \& technology red raspberry and its anthocyanins: Bioactivity beyond antioxidant capacity. Trends in Food Science \& Technology, Vol. 66, 153-165. https://doi.org/10. 1016/j.tifs.2017.05.015.

Verma, S., Singh, A., \& Mishra, A. (2013). Gallic acid: Molecular rival of cancer. Environmental Toxicology and Pharmacology, 35(3), 473-485. https://doi.org/10. 1016/j.etap.2013.02.011.

Viganó, J., \& Martinez, J. (2015). Trends for the Application of Passion Fruit Industrial By-products: A Review on the Chemical Composition and Extraction Techniques of Phytochemicals. Food and Public Health, 5(5), 164-173. https://doi.org/10.5923/j. fph.20150505.03.

Wang, H., Guo, X., Hu, X., Li, T., Fu, X., \& Liu, R. H. (2017). Comparison of phytochemical profiles, antioxidant and cellular antioxidant activities of different varieties of blueberry (Vaccinium spp.). Food Chemistry, 217, 773-781. https://doi.org/10.1016/j. foodchem.2016.09.002.

Wang, L.-S., \& Stoner, G. D. (2008). Anthocyanins and their role in cancer prevention. Cancer Letters, 269(2), 281-290. https://doi.org/10.1016/j.canlet.2008.05.020. 
Wiseman, H., \& Halliwell, B. (1996). Damage to DNA by reactive oxygen and nitrogen species: Role in inflammatory disease and progression to cancer. The Biochemical Journal, 313, 17-29. https://doi.org/10.1038/srep09969 Pt 1(2).

Wolfe, K. L., Kang, X., He, X., Dong, M., Zhang, Q., \& Liu, R. H. (2008). Cellular Antioxidant activity of Common Fruits Cellular Antioxidant activity of Common Fruits. Measurement, 56(August), 8418-8426. https://doi.org/10.1021/jf801381y.

Wolfe, K. L., \& Rui, H. L. (2007). Cellular antioxidant activity (CAA) assay for assessing antioxidants, foods, and dietary supplements. Journal of Agricultural and Food Chemistry, 55(22), 8896-8907. https://doi.org/10.1021/jf0715166.

Wu, T., Grootaert, C., Voorspoels, S., Jacobs, G., Pitart, J., Kamiloglu, S., ... Van, J. (2017). Aronia (Aronia melanocarpa) phenolics bioavailability in a combined in vitro digestion/Caco-2 cell model is structure and colon region dependent. Journal of Functional Foods, 38, 128-139. https://doi.org/10.1016/j.jff.2017.09.008.

Yan, Y., Liu, N., Hou, N., Dong, L., \& Li, J. (2017). ScienceDirect. The Journal of Nutritional Biochemistry, 46, 68-73. https://doi.org/10.1016/j.jnutbio.2017.04.007.

Yang, J., \& Liu, R. H. (2009). Synergistic effect of Apple Extracts and Quercetin 3- $\beta$ - d
-Glucoside Combination on Antiproliferative activity in MCF-7 Human Breast Cancer Cells in Vitro. Journal of Agricultural and Food Chemistry, 57(18), 8581-8586. https:// doi.org/10.1021/jf8039796.

Ye, Z.-W., Zhang, J., Townsend, D. M., \& Tew, K. D. (2015). Oxidative stress, redox regulation and diseases of cellular differentiation. Biochimica et Biophysica Acta (BBA) - General Subjects, 1850(8), 1607-1621. https://doi.org/10.1016/j.bbagen.2014.11. 010

Zhang, Q., Hu, X., Hui, F., Song, Q., Cui, C., \& Wang, C. (2017). Sciencedirect ethanol extract and its dichloromethane fraction of Alpinia oxyphylla Miquel exhibited hepatoprotective effects against $\mathrm{CCl} 4$-induced oxidative damage in vitro and in vivo with the involvement of Nrf2. Biomedicine \& Pharmacotherapy, 91, 812-822. https:// doi.org/10.1016/j.biopha.2017.04.131.

Zhishen, J., Mengcheng, T., \& Jianming, W. (1999). The determination of flavonoid contents in mulberry and their scavenging effects on superoxide radicals. Food Chemistry, 64(4), 555-559. https://doi.org/10.1016/S0308-8146(98)00102-2. 